\title{
The Curious Side of Modern Czech Nationalism
}

\author{
ZDENĚK L. SUDA* \\ University of Pittsburgh, USA
}

\begin{abstract}
The essay deals with some specific aspects of the Czech national idea and movement which set it apart from other national movements in Central Europe. It points out the contradictions inherent in the self-image of the Czechs and in their interpretation of their own history. It also draws the attention of the reader to the original contributions to the theories of nation developed by Czech thinkers, especially T. G. Masaryk and his disciples.
\end{abstract}

Czech Sociological Review, 2001, Vol. 9 (No. 2: 225-234)

The building process of the modern Czech nation was similar to the nation-building processes everywhere in Central and Eastern Europe: an ethnic group was brought to the awareness of its collective identity ('awakened') by an elite which eventually presented claims in its name to constitutional and international recognition. The 'totem', that is, the principal identity sign in this case, as in most other cases in the region, was the 'tongue', the specific Czech language. Yet there were notable differences, to the point that the birth of the modern Czech nation can be viewed as a phenomenon sui generis, a kind of historical curiosity. It is possible to ascertain such differences in several aspects.

\section{Cautious beginnings}

The first generation of the Czech 'awakeners', active at the turn of the 19th century, did not have any explicitly political goals in mind and was rather sceptical on this subject. Many saw the population, the existence of which they wished to bring to the attention of the European public, as a precious historical and cultural relic rather than a political agent. The Czechs in their view had a great past, but there was ambiguity about their future. The Czech ethnic group was situated the farthest west of all Slavic tribes and was virtually encircled by German-speaking elements. In Austria, of which it formed a part, the official language was German. German was adopted by all Czech classes above the peasantry, since its command was the condition for social advancement. Objectively, the chances of the emergence of a self-contained Czech nation were not very favourable at that time. To some contemporary observers it even appeared that, given the geopolitical location of the Czech group, it was likely to end up inside a German nation-state - when such a state would be created - in circumstances similar to those reserved for the Basques in France, or the Irish, Scots, and Welsh peoples in England/Great Britain; that the Czechs would ultimately be identified as tschechisch sprechende Deutsche, Czechspeaking Germans, similar to the tiny Slavic group of Sorbs living in Saxony who also referred to themselves as wendische sprechende Deutsche.

On the German side, this expectation prevailed even in the circles that otherwise were sympathetic to the efforts to preserve Czech language and culture. It persisted until the revolutionary wave of 1848/49 and its aftermath. In his analysis of Slavism in Bohe-

*) Direct all correspondence to: Prof. Zdeněk L. Suda, 115 South Oakhill Road, Pittsburgh, PA 15238-3021, e-mail zlsuda_1999@yahoo.com 
mia, Count Joseph M. Thun recommended to the Germans that they should wait and see whether, after all, the Czechs as a nation would not die out. He nevertheless explicitly rejected any measures that might speed up this process [Thun 1843]. At the height of the revolutionary movement, May 2, 1848, the leading German liberal daily, Augsburger Allgemeine Zeitung, stated that the Czechs in Bohemia did not have any other choice but to either become Germans or not to exist at all, meaning thereby the necessity for them to become part of the German nation-state, to remain part of German history. After the revolution failed, Karl Marx, in a commentary written for The New York Tribune, dismissed the possibility that the Czech ethnic group could ever develop into a full-fledged nation, and argued that such a nation was a figment of the imagination of a handful of learned Germans who had gone insane, citing the Czech historian and politician František Palacký as an example [New York Tribune, March 5, 1852]. Marx of course had his own agenda to pursue. National movements of ethnic minority groups inside larger states, like the Czechs in Austria or the Scots in Great Britain, were, in his opinion, impediments to the centralisation and the establishment of unitary bourgeois systems, which in their own turn were the precondition for the full development of capitalism, the growth of the industrial proletariat, and the socialist revolution. ${ }^{1}$

\section{Great-German illusions and the Czechs}

Whatever the idea may have been that the interested German circles in Austria and the neighbouring countries entertained about the nature and the prospects of the Czech national cause, by the time of the revolutionary upheaval of the 1840s it was too late to stop or re-direct its course. The predominantly historical and scholarly involvement of the early 'awakeners' had in the meantime been supplanted by outspokenly political concerns and commitments of the younger generations of leaders. More importantly, however, the movement had succeeded insofar as the Czechs 'woke up', became politically mobilised. Their appearance on the scene of the 1848 revolution, with a specific set of demands, testified to this fact unmistakably. The very first representations from the Czech lands made at the imperial court in Vienna saw a co-ordinated action by both the German and the Czech groups, but soon the two parted ways. The 'Czech Question' in Austria was thus tabled, never to disappear from the agenda.

In any event, it is questionable whether the solution which the partisans of the Great-German idea held in store for the Czechs relative to their place in Europe was realistic. The formula that had worked in France and England could in this case not be adopted, for the simple reason that the German counterpart to these two nation-states did not exist at that time. The German nation-building process, too, was different from that observed in Western Europe. The awareness of the Germans of their collective identity as

\footnotetext{
1) It is interesting to note that in presenting Palacký and other Czech leaders as learned Germans who had gone insane ("Mr. Palacký does not even know how to speak Czech!") Marx adopted the Great-German perspective on the German question, implying that it is the knowledge and the use of the German language that makes Germans and Germany ("wo immer die deutsche Zunge klingt" - "Germany is in all places where the German tongue sounds" - as the lyrics of the national anthem have it). Marx's Great-German (gross-deutsch) bias would not be too hard to document. His apparent scorn for the contemporary German intellectual and political scene, in fact, was an expression of his love-hate (Hassliebe) relationship to his native country, of a deep disappointment that it could not measure up to France and become an architect of world history.
} 
a nation preceded the constitution of a German state, whereas the modern French and English nations developed within pre-existing state frameworks. German experience in this respect was more or less typical of the entire Central and East European region; most nations there were entities in search of an institutional home, which accounted for much of the virulence of the endemic national conflicts.

Under these circumstances, the Great-German advice given to the Czechs was reminiscent rather of the proverbial blind man wanting to guide another blind man, with the easily predictable result. The German national state, as inspired by the Great-German idea and designed by the German liberals at the Frankfurt Assembly in 1848, never took shape. Instead, the so-called Small German formula was adopted, twenty-three years later, under a staunchly conservative leadership, which had no room for experiments of this kind. The appeal to the Czechs during the Prussian-Austrian war of 1866, approved by Bismarck, to rise against Austria, with the promise to help them obtain 'satisfaction of their rightful national aspirations', was no more than a propaganda warfare gimmick (which, by the way, fell on deaf ears among the targeted population). Bismarck's own very concept of Germany with Prussian predominance and his concern for the balance of powers in Europe made the inclusion of Austria or of a significant part of it, which the Czech lands indisputably represented, wholly illusory.

Yet this unrealistic proposition, doomed from the start, is not completely devoid of interest to an analyst today. The attempt to square the circle, to solve the antagonism between two nationalities by inviting one of them to freely give up its collective identity, contains an implicit recognition that the creation of a more or less homogeneous nationstate was not possible for the Germans in the Central and Eastern European area if this state was to comprise all German-speaking elements living there. The next logical step in this line of reasoning would have been the admission that not the ethnic but only the political concept of a nation was suitable to the given conditions. The German national movement, however, was neither willing nor able to make such a step.

Thus the solution of the German problem on the basis of the Small-German recipe, while it removed much of the ambiguity in the relation between the Germans and their neighbouring nations, including the Czechs, in no way signified the end of what could be called 'the German Question in Europe'. It left millions of individuals who identified as Germans outside the German national state, and therefore politically homeless. These gradually developed into the German version of irredenta which, not unlike its Italian analogue, would not settle for less than an all-inclusive yet ethnically pure Germany. They were not content with the role which the leaders of the German empire assigned to them: to ensure, by the weight of their numbers and their privileged position in Austria, that Vienna would never stray from the path of close alliance and co-operation with Berlin. They did not feel safe in an environment where they, though the most numerous and influential ethnic group, nevertheless constituted a statistical minority. Their apprehensions were especially strong in the lands of the Bohemian crown where they faced a clear Czech numerical superiority.

\section{The Peculiarities of the Czech Case}

Although the Czech national movement shared most of the problems and challenges of other national movements in the region, in some ways its position was different, especially as the Czechs themselves perceived it. They did not see their nation as uprooted, or uncertain about the boundaries of its homeland, for two important reasons: first, the 
Czech political leadership, until the Austrian-Hungarian Compromise of 1867 and even for a long time afterwards, considered Austria as the only conceivable political framework; second, within this framework the Czechs believed to have formed, since time immemorial, a distinct component, the Kingdom of Bohemia and the crown lands of St. Wenceslas. In fact, regaining for this component the status which it had enjoyed in the distant past was for a considerable time one of the principal aims of Czech politics. On this issue the Czechs could even count on support from the Bohemian nobility, both German- and Czech-speaking.

For the Czech nationalists, however, the glorious past of their country was not only a source of pride but also served immediate political purposes. It was supposed to legitimate Czech claims to the control of this homeland. In order that they should serve this end, simple historical facts had to be put in a certain perspective, had to be 'edited'. This again was nothing specifically Czech; re-interpreting history was an activity in which all national movements of that time engaged to a greater or lesser degree. German nationalists in the Bohemian crown lands - to cite an instance directly connected with the subject of our discussion - sought to justify the privileged, indeed the dominant, position of the German-speaking group by emphasising the continuity of German settlements and their contribution to the history of the country. These endeavours ranged from stressing the economic and cultural significance of the German colonisation of Bohemia under the Premyslid kings in the 12th century - which no serious historian could possibly dispute to fabricating theories such as the claim that Bohemia originally had been inhabited by Germanic tribes, the Bavarians, who later moved to the west, leaving Bohemia vacant, ultimately to be invaded by the Slavs. ${ }^{2}$

Among the Czechs, imagination did not run so wild as on the German side, yet there was a good deal of simplification of facts and of the projection of modern concepts, such as nation, into rather remote historical periods (this latter transgression, however, could be blamed on all nationalist interpretations of history in the 19th century). The Czechs, being a clear majority in the Bohemian crown lands, appeared to have it easier when they demanded a larger share of power than the imperial court in Vienna and the Austrian government were willing to award to them. Nonetheless, the majority argument, while certainly valid in the contemporary political dialogue, could hardly be convincingly employed in an historical context, although attempts of this kind were often made on the Czech side. It was difficult to legitimate Czech aspirations to leadership in the St. Wenceslas crown lands in the 19th century on the grounds that the Czech population there outnumbered the German in historical periods which did not know, let alone practise, the majority principle in the decision process and during which the nation, that is in

\footnotetext{
${ }^{2}$ ) It may be of interest that this particular theory, based mainly on the apparent but rather tenuous etymological likeness between the term 'Boios', the name given to the Celtic population of Bohemia of Roman time, and the designation 'Baiuvaren', given to the Teutonic tribe that settled Bavaria in the course of the great migration of peoples at the dawn of the Middle Ages, was resuscitated by the Nazi ideologists in the 1930s to support Hitler's claim to the Sudetenland and the rest of Czechoslovakia. As if in the last gasp of scholarly objectivity and intellectual honesty, the historians' college of the Prague German University (Professor Wostry) rejected the theory, but it did not prevent Hitler from using it in his speech of March 1939 in which he justified the occupation of Bohemia and Moravia, and the breach of the Munich Agreement which this move signified, before the German public.
} 
the politically active segment of the society, was limited to a very small percentage of the total.

\section{Anachronisms and Misapprehensions}

An example of such a rather liberal approach to historical facts can be seen in the manner in which the mainstream Czech nationalism interpreted the events of the period that it considered to have been crucial for the situation of the Czechs in modern Europe: that of the Thirty Years' War (1618-1648) and its sequel. It cannot be argued that the focus here was misplaced. This dramatic, turbulent chapter of history indeed profoundly marked and transformed the Czech society. The defeat of the revolt of Bohemia's Protestant estates against the Habsburg rulers in the battle of White Mountain, November 8, 1620, and the subsequent destruction of the country's elites by executions; the confiscation of their property and mass exodus; the drastic reduction of the status that Bohemia until then had enjoyed within the Habsburg empire, by the Renewed Provincial Constitution (Obnovené zrrízení zemské) introduced in 1627; and the unprecedented devastation of the entire Central European region during the three decades of war at the end of which less that a half of the original population remained; all that affected the Czech nation in the most adverse way.

However, the Czech national movement of the 19th century understood this social catastrophe as the outcome of an episode in the long history of the struggle between the Germans and the Czechs over the control of Bohemia and its crown lands. This interpretation borrowed, somewhat freely, from the theory advanced by František Palacký in his seminal work The History of the Czech People in Bohemia and Moravia. Actually, it was a projection of a problem of a society of the industrial age into the world of the late Renaissance. Overlooking, or at least underrating the fact that the social solidarities of the 17 th century were different from those of two hundred years later, as well as the essentially religious nature of the conflict, Czech nationalists created a skewed picture of what had really happened to their country during and immediately after the Thirty Years' War. This picture, unfortunately, gained considerable credence in wide circles of the Czech public, since it was peddled by popular press and literature as well as by many teachers at the institutions of education of all grades.

If the full long-term impact of the events of this critical phase of history upon the Czech society is to be correctly assessed, a different approach has to be adopted. To be sure, these events wrought havoc upon the Czech language and culture. Yet the Draconian punitive measures of the victor were not the work of the rival German ethnic group nor were they aimed at the Czechs as a nation, but at Protestantism; they hit the Germanspeaking Protestants with equal ruthlessness. Of course, taking into account the fact that over 80 percent of the Czech population at that time belonged to denominations other than Catholic, they came very close to becoming a threat to the very existence of the Czech national collective, if not a genocide. Nevertheless, considering the later political development of Central Europe, the real calamity visited upon this region in the wake of the Thirty Years' War has to be seen in the loss of religious pluralism brought about by the Counter-Reformation.

This loss was compounded and made quasi-permanent by the stipulation of the Treaty of Westphalia of 1648 endorsing the principle cuius regio, eius religio - 'the ruler determines the religious affiliation of his subjects'. Although it eventually brought peace to Europe in that it established tolerance among monarchs and countries, from the point 
of view of the evolution already reached by the Czech lands, it represented a step backward. There, religious tolerance and freedom on an individual basis had been achieved as early as the turn of the 17th century. It had been instituted by the 'Imperial Edict' of the Emperor Rudolph II in 1609 ('Majestát') and by local agreements among the estates such as the 'Bohemian Confession'. At that point virtually all inhabitants of the lands of St. Wenceslas crown could choose the church to which they wished to belong. It can be assumed that this state of affairs, had it continued, would have had a positive effect upon the development of Bohemia and its crown provinces; that religious pluralism, not unlike in England, might have paved the road to political pluralism and modernisation.

As a matter of fact, the benefits which could have been reaped from the preservation of religious pluralism would have been of a double nature. The national conflict that later was to dominate the Czech political scene could have been eased or dampened. The late 16th and early 17th century had already witnessed less of it, due precisely to religious diversity. It is possible to apply to the conditions, then prevailing in Bohemia, the theory of cleavages developed by political sociology [Lipset and Rokkan 1967]. In the terms of this theory, what happened there was that to the already existing ethnic and national cleavage another cleavage was added, namely religious. However, these two cleavages were not 'overlapping' - not all Czechs were Protestants nor were all Germans Catholics - but 'crosscutting', that is, both professions of faith were represented within both groups. This type of a situation is generally conducive to greater social stability and favourable to the development of a pluralist political order and democracy. It could be argued, too, that - allowing for the differences between the two historical periods - the early 17 th century nearly succeeded in solving the national problem in Bohemia which the 19th century was to find, for all practical purposes, intractable.

\section{Alternative Concept of the Czech Nation}

Learning from history is not too frequent a phenomenon, even with movements which, like the Czech national movement, so heavily depended on historical argument and justification. By the time this movement took shape, religious tolerance was no more an urgent issue, religious pluralism having been restored by an act of the enlightened absolute monarch Joseph II. Yet it did not translate into more tolerance in politics. German nationalists and their Czech counterparts continued to dream about ethnically homogeneous nation-states in a region which was the least suitable for their establishment. They did not realise that in seeking to homogenise the population of their country, by turning Czechs into Germans or vice versa, they became heirs to the tradition of Counter-Reformation, substituting religious exclusivity for ethnic exclusivity. In fact, nationalism in 19th century Europe did in many respects replace religion weakened under the impact of secularisation which was one of the aspects of the modernisation process. The societies of the Central European region made no exception.

Nevertheless, it was precisely among the Czechs that the established nationalist notions came to be challenged. In the 1890 s, a small group of intellectuals under the leadership of T. G. Masaryk, then professor at Charles University in Prague, opened a debate on what then was called the 'Czech Question', and the 'Meaning of Czech History'. They questioned the widely accepted idea of the nation as a community circumscribed by facts and forces external to its members and outside their control, such as race and language, and whose interests take precedence over the rights and interests of the individuals as well as over those of other nations. They doubted whether the mere existence and aggran- 
disement of a nation so conceived could justify the necessary sacrifices on the part of its citizens or command respect and recognition of mankind. Masaryk argued that a nation is not an accidental cluster of anthropologically similar humans but a body of conscious individuals bound together by a shared system of values. This bond he called a "programme' [Masaryk 1895].

This debate, which was very lively and occasionally became even acrimonious, centred of course on the Czech nation and its situation in the world. Mainstream patriots were rather shocked that anybody should dare questions its raison d'etre or ask whether working for it was worth the trouble. The idea of a programme as an identity sign of a nation, however, had far-reaching implications. It reduced the importance of nature-given similarities between and within ethnic groups - among others, it pointed to the illusory nature of Panslavism - and allowed for free choice of national affiliation based on the choice of the programme. A nation so defined could not be other than political. This was not compatible with the until then generally accepted image of the Czech nation and of the duties of a Czech patriot. Developed further by Masaryk's disciple Emanuel Rádl [Rádl 1929], the theory provided a basis for a separate school of political philosophy notably remote from those that had inspired mainstream Central European nationalism. Its input, too, represents a specific Czech aspect of this phenomenon.

Masaryk did not succeed in converting the core of Czech nationalists to his views. This is curious since he later became the principal architect of an independent national state of the Czechs and made reality the dream of several generations of Czech national leaders. As if by a paradox, the success of his liberation campaign during World War I, instead of lending authority to his views on the problem of modern nations, rather reinforced the established nationalist opinions and prejudices. This despite the fact that the First Czechoslovak Republic, not unlike Austria-Hungary, was a multiethnic state where political nationality would have been a more appropriate formula than the actually adopted distinction between the state-bearing Czechoslovak nation and minority nationalities. Such an option would have engendered more loyalty among the minority groups and provided more internal stability. Seen from this point of view, the political entity founded by Masaryk in 1918 was not truly 'Masaryk's republic'.

\section{The Three Tragedies}

Consistent application of the principle of political nationality, of course, would have had even more beneficial effects in Austria prior to the 1914-18 war. It could have saved the Danubian empire; actually, it was the only way this empire could have been saved. The preconditions for the pursuit of this course were all given. To the letter the Austrian constitution did not discriminate between individual nationalities; all were Austrian citizens, subjects of His Apostolic Majesty, the Emperor. The name of Austria, being a geographic term, had the inestimable advantage of being also nationality-neutral - something that later could not be asserted about, for example, Czechoslovakia.

However, the long-standing everyday practice of government and administration in Austria belied these principles and made it difficult to take advantage of them, in a similar way that the prerogative of the imperial court to determine the country's foreign policy and decide about war and peace flawed the image of Austria as a constitutional state. The privileged position of German as the official language could be justified as a practical necessity in a multinational empire; less so the circumstance, for example, that the institutions of higher-education teaching in German represented 75 percent of the univer- 
sity system although only one third of Austria's population declared German to be their language of communication (Umgangssprache) in the 1910 census. The recruitment for civil service positions at higher levels, for example in the diplomatic sector, clearly favoured German-speaking candidates over members of other nationality groups. (A channel of upward occupational mobility though, open to all ethnic elements virtually without restriction, was the military career.) The overt sympathy of the emperor for everything German did not help, either, the delicate climate reigning among Austria's most numerous nationalities; his statement, "Ich fühle mich als ein deutscher Fürst" - "I consider myself to be a German duke" - was very unfortunate indeed.

Yet, as far as the perceptions of the Czechs and their attitude towards Austria are concerned, the ambiguous and inconsistent dealing of the Viennese government with the 'Czech Question', that is, with the political and cultural aspirations of the Czechs and their status within the empire, was by far the most damaging. Admittedly, the task was not easy on account of the nationalist passions on both the Czech and the German side, especially the latter. For while the spokesmen of the Czechs may at times have complicated the negotiations through excessive demands or unrealistic expectations, the systematic stubborn resistance to any meaningful compromise shown by the German nationalist faction rendered a solution nearly impossible. The opposition did not include all Germanspeaking elements in Austria, but a coalition to this purpose was repeatedly formed by the representatives of the constituencies in Vienna and the border regions of Bohemia, Moravia and Silesia (later called 'Sudetenland'), that is, by the districts where the contacts between the Czechs and the Germans were the most immediate and frequent, and where an arrangement, eventually agreed upon, was the most likely to be put to a test.

This opposition frustrated several attempts at the resolution of the 'Czech Question' among which the project of the so-called Fundamental Points of Agreement sponsored by the Hohenwarth ministry in 1874 was the most significant. Its failure caused great bitterness among the Czechs, which did not turn so much against the German foes of the project, whose hostility they had taken more or less for granted, as against the imperial government that on this, and other similar occasions, yielded to the oppositional pressure. The resentment was all the more acerbic since the proposals were usually not defeated by a majority vote in the Imperial Council (Reichsrat) but abandoned by the sponsors after their adversaries set the mob in motion and provoked riots in the streets of Vienna. One of the most fateful mistakes of the Austrian establishment in handling the Czech issue was committed when emperor Francis Joseph I reneged on his promise, given in 1870, to be crowned as King of Bohemia. He did so obeying a secret clause of the Austrian-Hungarian Compromise Treaty of 1867 whereby he had committed Austria not to grant any other component of the Habsburg monarchy a status comparable to that of Hungary. After these experiences, the Czech national movement, for which until then the preservation of the Austrian state framework had been a near axiom, embarked upon a different path later called 'catastrophic'. The Czechs were willing to identify as Austrian citizens, but not as citizens of a lower rank. ${ }^{3}$

3) Thus the inability of the Austrian powers to come to terms with the Czechs, in combination with the lack of genuine loyalty on the part of a considerable and influential segment of the most favoured ethnic group, the Germans, eventually spelled a tragedy. However, it was not to be only the Austrian tragedy. The subjectively homeless, uprooted orphans of the Great-German dream, unsure of their collective identity, alas, were predestined to bring about greater calamities than just 232 


\section{More Curiosa and Some Hope}

The circumstance that Austria in the end was subverted by the revolt of its erstwhile most loyal ethnic component may be viewed as one of the curious sides of Central European and Czech nationalism. There was yet another curiosity connected with this event: the destructive act itself and the creation of an independent Czech national state were carried out by a politician and thinker who rejected the nationalist ideology of the 19th century. Yet, as we have already observed, the success of his liberation campaign did not convince the majority of the public in his country about the correctness of his idea of a nation. That, too, was somewhat curious. The new state, measured by Masaryk's own yardsticks, could be legitimated only if it were more equitable than that on the ruins of which it was founded and if it succeeded in solving the problems which Austria proved unable to handle. This could be affirmed only in part; Czechoslovakia after 1918 was a free society, more egalitarian and democratic than Austria, but it had to wrestle with a new set of nationality conflicts.

An impartial judgement about the First Czechoslovak Republic's performance in this respect, of course, has to take into account that it had a very short time to prove itself. International development since the end of World War I was on the whole unfavourable to the pursuit of policies inspired by Masaryk's principles. It rather confirmed and reinforced the traditional assumptions and stereotyped images of mainstream Czech nationalism. Germany soon revealed itself again as a threat to Czech independence and even to its plain survival as a nation. The transfer of the German-speaking population from the Czechoslovak territory after 1945 was motivated and justified by this traumatic experience. In fact, however, it was a reversed copy of the German attempt to achieve something which the given ethnic structure of Central Europe would never permit: the formation of a homogeneous comprehensive nation-state of one nationality.

The social, economic and moral ravages of the real socialist experiment that followed upon the heels of this drastic operation - and to a significant extent was facilitated by it - taught the Czechs a costly lesson about the problematic blessings of ethnic purity in a society that treasures freedom. They also highlighted the fallacy of the dichotomy between individual and national liberties, typical of Czech traditional nationalism. The Czechs realised that mere international status of a sovereign state does not guarantee freedom to its citizens; that a nation is free only if each of its members is free. Forty years spent in the role of a Soviet satellite, too, brought again to their attention the merits of the alternative concept of national solidarity presented by Masaryk, a solidarity based not on external anthropological or linguistic affinities but on a consensus about basic social values.

Accepting this concept implies giving up the idea of the state as a fortress of an exclusionist human group keeping out everything that is different, and consenting to a life in ethnic, racial and cultural plurality. Such a step, made a century earlier, might have saved Austria, then a political and social configuration of undisputed promise. If imple-

preventing the accommodation of a small Slav nation within the Danubian empire. Two generations later, one specimen of this hapless group became the absolute ruler of Germany and put the dream of a homogeneous all-comprising German national state in Central Europe in reality the only way it was possible: be means of deportations, concentration camps, and gas chambers. The tragedy turned out to be triple: it affected not only Austria and the Czechs but also Germans themselves as a nation. 
mented more consistently, it might have lent more stability and internal security to the First Czechoslovak Republic. However, what is more important than these historical revelations is the fact that in adopting this perspective on the nation and the relations among nations the Czech society will prepare itself in the best possible way for the international order of tomorrow, concretely, for membership in an integrated democratic Europe.

ZDENĚK L. SUDA is Professor Emeritus of Sociology at the University of Pittsburgh where he taught from 1968 till 1985. He holds a PhD from Charles University in Prague, M.A. from the University of Geneva, and diploma of the College of Europe in Bruges. After November 1989, he was associated with the Central European University in Prague, where he organised courses of Sociology, and worked with Professor Jiři Musil on the study and research project 'German Society and Politics in the European Context'. He also helped establish the department of social sciences at the Silesian University in Opava of which he was the chairman for several years. He is author of a number of publications, among them Zealots and Rebels: The History of the Communist Party of Czechoslovakia (Stanford 1981); Globalization of the Labor Markets: a Challenge to the Social Contract (Paris and Prague, 1994); La Division Internationale Socialiste de Travail (Leiden 1967); Liberalism East and West (in collaboration with Jiři Musil, Budapest 1999).

\section{References}

Lipset, Seymour M., Stein Rokkan (eds.) 1967. Party Systems and Voter Alignments: CrossNational Perspectives. New York: Macmillan.

Masaryk, T. G. 1969 (1895). Česká otázka [The Czech Question]. Praha: Melantrich.

The New York Tribune 1852. March 5.

Rádl, Emanuel 1929. Národnost jako védecký problém [Nationality as a Scientific Problem]. Praha: Girgal.

Thun, Leopold L. 1843. Die Stellung der Slowaken in Ungarn. Prag: Palve. 